\title{
INTERNET USE BY THE OLDER ADULTS IN THE CZECH REPUBLIC
}

\section{Blanka Klímová, Petra Poulová, Ivana Šimonová, Pavel Pražák, Anna Cierniak-Emerych}

\section{Introduction}

The problem of the developed countries is the aging of the population. Developing countries, for the time being, do not experience it so urgently yet due to the lower average age of the population, but their standard of living is also beginning to improve. In 2000 , the percentage of older individuals aged $65+$ years reached $12.4 \%$. In 2030 , this number should rise to $19 \%$ and in 2050 to $22 \%$ (Transgenerational, 2009). In Europe this population group aged 65+ represent $18 \%$ of the 503 million Europeans, which should almost double by 2060 (Patterson, 2006). This trend of aging population causes additional problems such as increased costs on the treatment and care of those elderly people (Maresova et al., 2015a; 2015b). Therefore, there is ongoing effort to extend the active life of this group of people in order to allow them to stay economically and socially independent. And current technological devices and services can assist them in this process.

There is a significant drop in the rates of internet adoption between the groups of older and younger individuals across all different contexts and subgroups among the nations (Dutton et al., 2009; Zickuhr \& Madden, 2012). Even within the group of older adults can the relationship be defined as linear, because the group with lowest rates of internet usage are the most senior (Dutton et al., 2009; Friemel, 2016; Gell, Rosenberg, Demiris, LaCroix, \& Patel, 2015; Zickuhr \& Madden, 2012). For example, in the United states $79 \%$ of people in age under 45 years would go online, while in the group of people aged between 45 and 64 the rate drops to $76 \%$, there is significant drop to $52 \%$ in that rate for people 65 years old and older. Furthermore, not only do older adults fall behind in simple internet access, they also fail to keep up with the widespread faster broadband connections. Seniors often choose an offline, analogue, face-to-face alternative for the digital technologies that other parts of society include to their everyday lives (Taha, Sharit, \& Czaja, 2009; Yuan, Hussain, Hales, \& Cotten, 2016). While choosing comfort of these offline, analogue choices, seniors miss out on the many advantages provided by online interactions.

The advanced age leads to shrinking of the social networks of the older adults which often results in loneliness. Engaging in online activities can suppress such feelings. The digital divide by age is troubling, given the amount of diverse benefits for older adults who go online. (Cotten, Anderson, \& McCullough, 2013; Fokkema \& Knipscheer, 2007; Shillair, Rikard, Cotten, \& Tsai, 2015). The internet users among older adults have also shown less limitations in their daily lives than the nonusers (d'Orsi, Xavier, Steptoe, de Oliveira, Ramos, Orrell, Demakakos, \& Marmot, 2014). Using the internet has also shown an improvement in older adults' lives, their perception of themselves, satisfaction with their life and the meaning of it, their self-efficacy and how others evaluate them (Lelkes, 2013). The diversity in benefits of the internet use presses us to get a better understanding of the reasons that are holding more members of the populations from using online services.

Recent research studies (Hanson, 2009; Hernandez-Encuentra et al., 2009; Sayago et al., 2011; Heart \& Kalderon, 2013) have also proved that older generation of people, aged 58-77, are nowadays much more digitally aware than they used to be ten years ago. Currently, more and more people use the Internet. For example, in the USA $64 \%$ of older individuals aged $65+$ years exploit the Internet (Pew Research Center, 2017), in the Great Britain the number of people aged 65+ years has reached $74 \%$ (Office for National Statistics, 
2016), and in the Netherlands it is even more $-78 \%$ of older people use it (van Boekel et al., 2017). This is caused not only by acquiring more experience through different kinds of community and nationwide projects aimed at older people (Bishop, 2009; Godfrey \& Johnson, 2009), but also their desire to communicate with their family, e.g. grandchildren, or to find the information they need. Seniors tend to have a lot of free time, so they use the internet to engage in networking and communications on social media and seek various entertainment online.

Generally, there are three main preconditions that are conductive to the rising use of ICT by older people. These include:

- an increase in the number of older people worldwide;

- ICT as a tool for providing older people with the promise of greater independence;

- the generation of "baby boomers" approaching retirement being relatively comfortable using ICT; they will bring many technology-related skills into their retirement years. (Virginia, 2011; Klimova, 2016)

Older adults do not form a heterogeneous demographic group since according to the declining age, they have different needs, which place the older people into three different groups: $55-64$ years old, $65-74$ years old, 75 and more years old. (Klimova et al., 2016; Klimova, 2017)

The purpose of this study is to explore the use of the Internet among older people in the Czech Republic with respect to their age.

\section{Materials and Methods}

The research methodology is introduced in four subchapters comprising (1) the research question and the main research objective, (2) research sample, (3) hypotheses and (4) the tool for testing the hypotheses.

\subsection{Research Question and Objective}

The current life is characterized by two main features: (1) living in the i-society, where ICT devices have penetrated all spheres of life, and (2) the growing amount of senior population, which requires supporting the development of important skills (competences) necessary for living in the i-society which might be new for them in some aspects.

Therefore, the answer to the question how seniors exploit the ICT devices and the Internet in common life is highly topical. Coherently, the research questions focus on two areas:

(1) Do seniors exploit the Internet?

(2) Is the Internet exploitation impacted by respondents' age?

Reflecting the above mentioned, the main research objective is to discover whether seniors use the Internet and whether the Internet exploitation depends on user's age.

\subsection{Research Sample}

Totally, 432 respondents participated in the research. They all were residents of Hradec Kralove district and both seniors with active and passive approach to the ICT competence development were represented in the sample. All respondents were physically and mentally healthy and were structured in three groups:

(1) the so-called 'passive' seniors, i.e., those who do not want to pay attention to acquiring any knowledge of the latest ICT and their exploitation, were represented by respondents living in senior houses (group 1, DD, $n=108$ );

(2) the so-called 'active seniors' interested in their further education, particularly in the ICT field and who attended ICT courses held by the Hradec Kralove municipality (group 2, HK, $\mathrm{n}=159$ );

(3) the so-called 'active seniors' interested in their further education in general who attended courses of the University of the Third Age (group 3, U3V, $n=164$ ).

As the 'passive' seniors are represented by one group of the institutionalized respondents and other 'passive' seniors have not been included in the sample, the authors are aware of the fact that the research sample is of a selective type, not representing the whole population but dealing with its characteristics in several features only, i.e. in the male/female structure. Consequently, the results cannot be generalized, but they can serve as an introductory study for further deeper research activities.

The age of 55 is the starting seniors' age in the Czech Republic (Czech Statistical Office, 2017a). The respondents' age ranged between 55 years (born in 1961) and 94 years (born in 1922) in 2016, when the research was conducted. The sample consisted of 317 female $(F, 73 \%)$ and 11 male respondents $(M, 17 \%)$ - this distribution follows the structure of the Czech senior population. (Czech Statistical Office, 2017b) There were 15 respondents 


\section{Fig. 1: Research sample: age/gender structure of the research sample (n)}

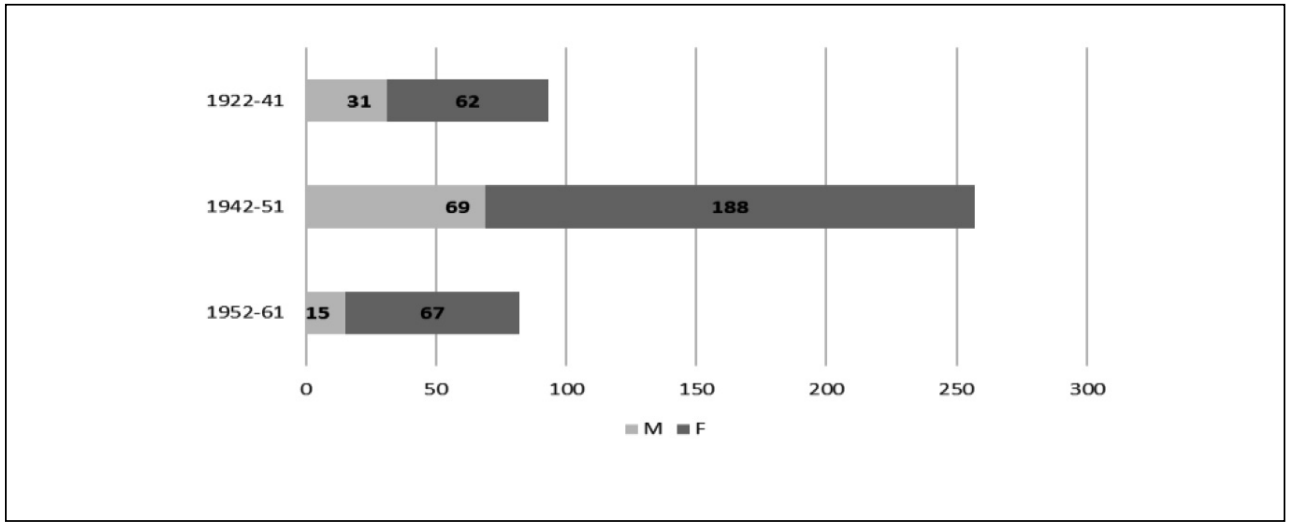

Source: own

$85+$ years old -12 females and 3 males. Most of the respondents (257; F 188; M 69) were born in the period of 1942-1951, i.e., they were 65-74 years old; the oldest ones were $87+$ years old (Fig. 1). For the purpose of this research, respondents were structured into three age groups (55-64-year old: 82 respondents; 65-74-year old: 257; 75+-year old: 93), which is a rather common approach, cf. (Benáčová \& Valenta, 2009; Slavik, 2012).

\subsection{Hypotheses}

Totally, five hypotheses were tested, three of them relating to the Internet exploitation by the seniors and other two to the impact of respondents' age on the Internet exploitation.

Ad1) Do seniors exploit the Internet?

$H 1_{1}$ : Respondents in group 2 (HK, participants of ICT courses) exploit the Internet more compared to respondents in group $1(D D$, living in senior houses).

$\mathrm{H}_{2}$ : Respondents in group 3 (U3V, participants of U3V courses) exploit the Internet more compared to respondents in group 1 (DD, living in senior houses).

$H 3_{1}$ : Respondents in group 2 (HK, participants of ICT courses) exploit the Internet more compared to respondents in group 3 (U3V, participants of U3V courses).

Ad2) Is the Internet exploitation impacted by respondents' age?
$H 4_{1}$ : The proportion of Internet users in 55-64 age group is higher compared to 65-74 age group.

$\mathrm{H5}_{1}$ : The proportion of Internet users in 65-74 age group is higher compared to $75+$ age group.

\subsection{Research Tool}

The questionnaire was distributed by the researchers in the senior houses, ICT courses and U3V courses. In the lounge of the senior houses, or after one of the course lessons respondents were provided with basic information on the purpose of the research and they filled in the questionnaire in the printed form.

The questionnaire took approximately 15 minutes and comprised 10 items covering

- personal data (Q1: gender, age, level of education),

- three yes/no questions (Q2: Did you use ICT in your profession?; Q7: Do you exploit the Internet?; Q9: Do you exploit the Internet in your mobile/smart phone?),

- five multiple-choice questions with one or more answers from 6-12 distractors (Q3: What ICT devices do you own?; Q4: What ICT devices do you use?; Q6: How did/do you acquire the ICT skills/competences?; Q8: What Internet services do you exploit?),

- one open-answer question (Q10: Can you imagine your life without electronic devices? Why?).

One year before the research started, the questionnaire had been piloted in the group of 22 respondents - participants of ICT courses 
and adjusted to its present final form.

The collected data were processed by the ' $R$ ' software version 2.5.1. (The R Project for Statistical Computing, 2017)

\section{Research Results}

The presentation of the research results is structured into three parts which follow the research questions:

(1) Do seniors exploit the Internet?

(2) Is the Internet exploitation impacted by the respondents' age?

The process of testing hypotheses included the following steps:

- collected data were displayed in the contingency table,

- Chi-Square Test of independence was conducted,

- Proportion and Confidence Interval were calculated and $p$-value computed.

\subsection{Do Seniors Exploit the Internet?}

The data in this field were collected from one item of the questionnaire. They are summarized in the contingency table below (Tab. 1), in total and in groups 1-3.

\section{Tab. 1: Internet exploitation in Groups of Seniors: the contingency table and of qualitative characteristics}

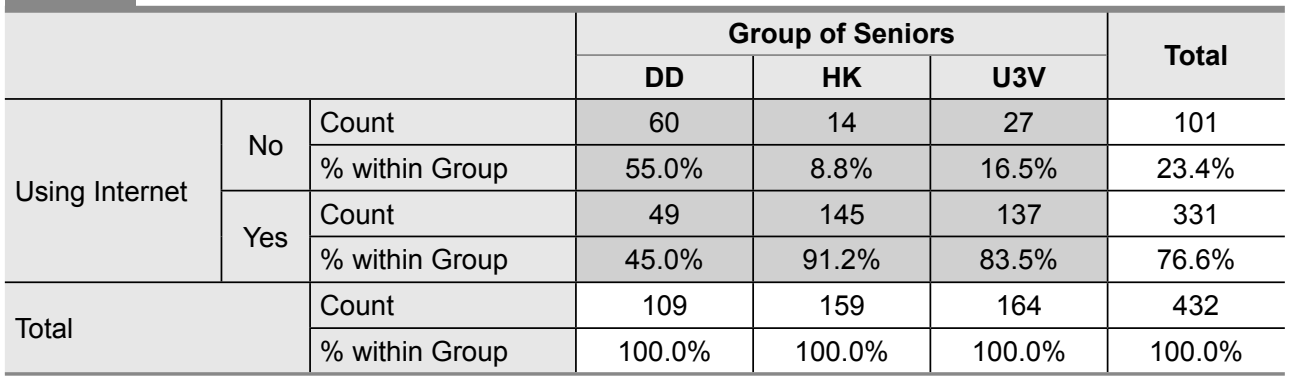

Tab. 2: $\begin{aligned} & \text { Results of Chi-Square Tests for independence of the use of the Internet } \\
& \text { and Group of Seniors }\end{aligned}$
\begin{tabular}{l|c|c|c} 
& Value & df & p-value \\
\hline Pearson Chi-Square & 84.249 & 2 & $<2.2 \mathrm{e}-16$ \\
\hline $\mathrm{N}$ of Valid Cases & 432 & & \\
\hline
\end{tabular}

\section{Tab. 3: Proportion of the Internet exploitation in single groups}

\begin{tabular}{l|c|c}
\multicolumn{1}{c|}{ Group of Seniors } & Proportion & 95\% Confidence Interval \\
\hline DD & $p_{D D}=0.450$ & $(0.355,0.548)$ \\
\hline HK & $p_{H K}=0.912$ & $(0.854,0.949)$ \\
\hline U3V & $p_{U 3 V}=0.835$ & $(0.768,0.887)$ \\
\hline
\end{tabular}

Source: own

The results show that the Internet is widely used by the 'active' respondents in group 2 (HK, participants of ICT courses; $91.2 \%$ ), followed by group 3 (U3V, participants of U3V courses;
$83.5 \%$ ), whereas more than half of the 'passive' respondents (DD, respondents living in senior houses; $55 \%$ ) do not exploit the Internet. 
Applying the Pearson chi-square test of independence on the 0.05 significance level, the following conclusion can be found: using internet is not independent of groups of seniors. The results are displayed in Tab. 2 .

In order to receive detailed results in single groups, the proportions between them were compared. The calculations of proportion and confidence interval were based on the data in Tab. 1 and displayed in Tab. 3.

Further on, hypotheses $\mathrm{H} 1, \mathrm{H} 2, \mathrm{H} 3$ stating that:

$H 1_{1}$ : The proportion of respondents in group 2 (HK, participants of ICT courses) is higher compared to the proportion in group 1 ( $D D$, living in senior houses).

$\mathrm{H}_{1}$ : The proportion of respondents in group 3 (U3V, participants of U3V courses) is higher compared to the proportion in group 1 ( $D D$, living in senior houses).

$H 3_{1}$ : The proportion of respondents in group 2 (HK, participants of ICT courses) is higher compared to the proportion in group 3 (U3V, participants of U3V courses).

were tested according to Tab. 4.

The z-test was applied for considering the difference of two population proportions (Groebner et al., 2007); the results are displayed in Tab. 5. In the table, instead of z-statistics, which shows an approximate normal distribution, the chi-square distribution of 1 degree of freedom is displayed, which is valid if the null hypothesis is verified.

The results show that on the 0.05 significance level, hypotheses $\mathrm{H} 1, \mathrm{H} 2$ and $\mathrm{H} 3$

\section{Tab. 4: Hypotheses H1, H2, H3 on the proportion of the Internet exploitation in the single groups of seniors}

\begin{tabular}{l|c|c} 
& Null Hypothesis & Alternative Hypothesis \\
\hline $\mathrm{H} 1$ & $p_{H K}=p_{D D}$ & $p_{H K}>p_{D D}$ \\
\hline $\mathrm{H} 2$ & $p_{U 3 V}=p_{D D}$ & $p_{U 3 V}>p_{D D}$ \\
\hline $\mathrm{H} 3$ & $p_{H K}=p_{U 3 V}$ & $p_{H K}>p_{U 3 V}$ \\
\hline
\end{tabular}

Source: own

Tab. 5: Results of testing hypotheses H1, H2, H3 for the difference between two population proportions

\begin{tabular}{c|c|c|c}
\multicolumn{1}{c|}{ Test } & X-squared & df & p-value \\
\hline $\mathrm{H} 1$ & 66.90 & 1 & $<2.2 \mathrm{e}-16$ \\
\hline $\mathrm{H} 2$ & 43.10 & 1 & $2.556 \mathrm{e}-11$ \\
\hline $\mathrm{H} 3$ & 3.61 & 1 & 0.02873 \\
\hline
\end{tabular}

Source: own

were verified; on the 0.01 significance level, hypotheses $\mathrm{H} 1$ and $\mathrm{H} 2$ were verified, whereas hypothesis $\mathrm{H} 3$ could not be statistically proved.

These results mean that on the 0.05 significance level there exist statistically significant differences between the groups of the respondents living in senior houses (Group 1, DD), attending ICT courses (group 2 ICT) and U3V courses (group 3, U3V) in the Internet exploitation as follows: respondents in group 2 (HK, participants of ICT courses) exploit the Internet more compared to the respondents in group 1 (DD, living in senior houses); respondents in group 3 (U3V, participants of U3V courses) exploit the Internet more compared to group 1 (DD, living in senior houses); respondents in group 2 (HK, participants of ICT courses) exploit the Internet more compared to the respondents in group 3 (U3V, participants of U3V courses).

On the 0.01 significance level, statistically significant differences were detected between group 2 (HK, participants of ICT courses) whose respondents exploit the Internet more compared 
to the respondents in group 1 (DD, living in senior houses) and group 3 (U3V, participants of U3V courses) who exploit the Internet more compared to the respondents in group 1 (DD, living in senior houses). Statistically significant differences between group 2 (HK, participants of ICT courses) and group 3 (U3V, participants of U3V courses) could not be proved.

\subsection{Is the Internet Exploitation Impacted by the Respondents' Age?}

Reflecting on the date of birth, all seniors were categorized in three age groups: $55-64$ year-old (born 1952-1961), 65-74 year-old (born 19421951) and 75+ year-old (born 1922-1941). The structure is displayed in the Tab. 6 .

The data show a continuous decrease in the Internet exploitation in relation to the respondents' age. Whereas the Internet was used by more than half $(52.7 \%)$ of the oldest respondents (aged 75+, born 1922-41), which is rather high rate, the proportion surpassed $80 \%$ of the users in the respondents aged 74-65 (81.8\%; born 1942-51) and those aged 64-55 (87.7\%; born 1952-61). The results are displayed in Fig. 2 below.

\begin{tabular}{|c|c|c|c|c|c|c|}
\hline \multirow[t]{3}{*}{ Tab. 6: } & \multicolumn{6}{|c|}{$\begin{array}{l}\text { The Internet exploitation according to the respondents' age in the single groups } \\
\text { of seniors: The contingency table of qualitative characteristics Internet } \\
\text { exploitation and respondents' age }\end{array}$} \\
\hline & & & \multicolumn{3}{|c|}{ Age groups } & \multirow{2}{*}{ Total } \\
\hline & & & $55-64$ & $65-74$ & $75+$ & \\
\hline \multirow{4}{*}{$\begin{array}{l}\text { Exploiting } \\
\text { the Internet }\end{array}$} & \multirow{2}{*}{ No } & Count & 10 & 47 & 44 & 101 \\
\hline & & $\%$ within Age Group & $12.3 \%$ & $18.2 \%$ & $47.3 \%$ & $23.4 \%$ \\
\hline & \multirow{2}{*}{ Yes } & Count & 71 & 211 & 49 & 331 \\
\hline & & $\%$ within Age Group & $87.7 \%$ & $81.8 \%$ & $52.7 \%$ & $76.6 \%$ \\
\hline \multirow{2}{*}{ Total } & & Count & 81 & 258 & 93 & 432 \\
\hline & & $\%$ within Age Group & $100.0 \%$ & $100.0 \%$ & $100.0 \%$ & $100.0 \%$ \\
\hline
\end{tabular}

Source: own groups (0: respondents who do not use the Internet; 1: Internet users)

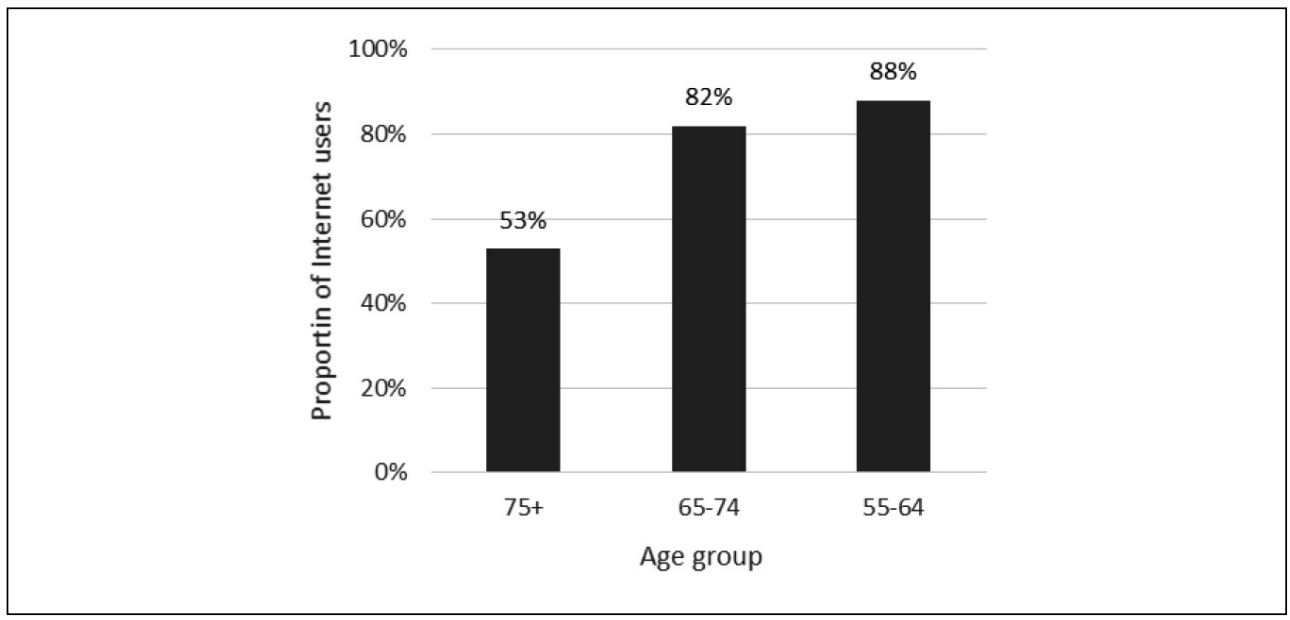




\section{Informační management}

The tendency of increasing proportion of the Internet users in 'younger' age groups was tested by hypotheses $\mathrm{H} 4$ and $\mathrm{H} 5$ stating that:

H4 $4_{1}$ : The proportion of Internet users in 55-64 age group is higher compared to 65-74 age group.

H5 $5_{1}$ : The proportion of Internet users in 65-74 age group is higher compared to $75+$ age group. Tab. 7.

Hypotheses were verified according to

Tab. 7:

Hypotheses on the proportion of the Internet exploitation in single age groups of seniors

\begin{tabular}{c|c} 
Null Hypothesis & Alternative Hypothesis \\
\hline$p_{55-64}=p_{65-74}$ & $p_{55-64}>p_{65-74}$ \\
\hline$p_{65-74}=p_{75+}$ & $p_{65-74}>p_{75+}$ \\
\hline
\end{tabular}

Source: own

\section{Tab. 8: Results of testing hypotheses 4-5 for the difference between two population proportions}

\begin{tabular}{c|c|c|c}
\multicolumn{1}{c|}{ Test } & X-squared & Df & p-value \\
\hline $\mathrm{H} 4$ & 1.13 & 1 & 0.144 \\
\hline $\mathrm{H} 5$ & 28.6 & 1 & $4.368 \mathrm{e}-08$ \\
\hline
\end{tabular}

Source: own

\section{Fig. 3: Frequency of the use of the Internet by the respondents}

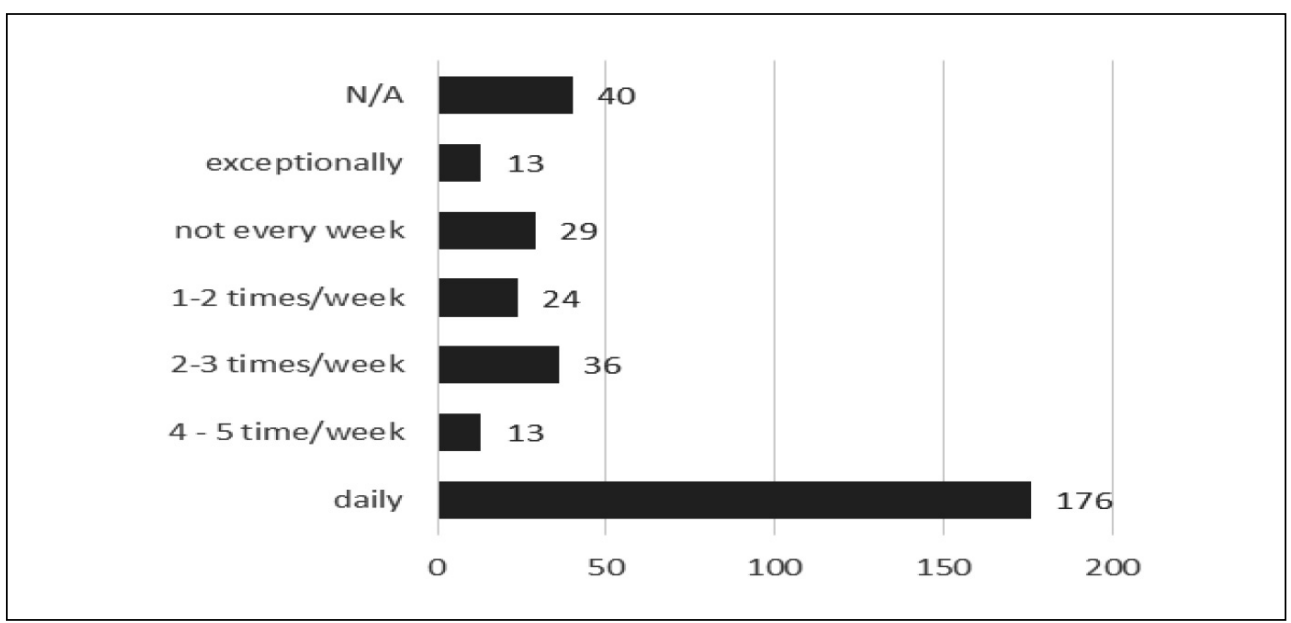


difference was not discovered between groups of the 55-64 year-old respondents (born 1952-61) and 65-74 year-old ones (born 19421951). The statistically significant difference was detected between the respondents 65-74 year-old (born 1942-1951) and 75+ year-old (born 1922-1941).

In addition to the main hypotheses, the authors examined the frequency of the use of the Internet by these older individuals. The findings revealed that more than half of the respondents $(53 \%)$ exploited the Internet on a daily basis and another $22 \%$ of the respondents used it at least once a weak (Fig. 3).

Furthermore, the authors also dealt with the issue of the Internet activities seniors are engaged in. $72 \%$ of the respondents use the Internet for communication and the main tool for it is e-mail. Almost two fifths (38\%) of seniors also use Skype for communication. Surprisingly, the second most used service on the Internet was electronic banking (e-banking $-40 \%$ of the respondents), closely followed by Skype, photo sharing $-38 \%)$. One third of the respondents also reported that they did shopping via the Internet (33\% of the respondents) and the same number of seniors looked for health information on the Internet. A quarter of respondents read a variety of blogs ( $3 \%$ even actively created them) and $15 \%$ of them spent time on playing different online games.

The survey showed that almost none of these seniors nowadays cannot imagine life without the Internet. As they pointed out, it was part and parcel of their present life.

\section{Discussion}

The results reveal that more and more older adults exploit the Internet nowadays and more than half of them exploit it on a daily basis. This is especially true for the age groups (55 years up to 74 years). The breakthrough age in the decrease in the use of the Internet among these people is then 75 years, which is quite common in the developed countries and it is connected with the overall deterioration of cognitive functions at this age (Klimova \& Maresova, 2017). This finding has been also confirmed by van Boekel et al. (2017) who report that people reaching the age 74+years spend the least time on the Internet. The same was discovered by Smith (2014), de Veer et al. (2015), or Zickuhr and Madden (2012). Nevertheless, even in this age group ( 75 +years) the situation is improving since the number has almost doubled in five years cf. (van Boekel et al., 2017; Smith, 2014).

The findings suggest that those attending specialized ICT courses had more experience in their use and thus, were more confident and frequent users than those in senior houses and the attends of the University of the Third Age. This fact was also indicated by Choi and DiNitto (2013), who claim that older people need to be trained in the Internet use for various purposes since the Internet plays the significant role in their social capital, as well as in removing their psychological barriers. Zheng et al. (2013) suggest that older individuals, especially those who feel lonely, should be a target.

Generally, older people use the Internet for communication purposes with the help of e-mail, the most frequent ICT tool for this generation group cf. (Hola \& Pikhart, 2014; Gell et al., 2015; Sayago \& Blat, 2010; Prior et al., 2008). Nevertheless, the findings of this study indicate that the second most common reason for the use of the Internet is the Internet banking, followed by Skype communication and photo sharing cf. (Benáčová \& Valenta, 2009; Brush, 2008; Cerna \& Svobodova, 2014). Similar results were achieved by Choi and DiNitto (2013), who report that their older Internet users were engaged in diverse types of Internet activities; almost $86 \%$ of the users sent emails/text messages, $51 \%$ shopped, paid bills, and/or did banking, and $45 \%$ conducted healthrelated tasks on the Internet. The most recent study by van Boekel et al. (2017) distinguished four main clusters of the older Internet users. These include minimizers, aged 74 years, who exploit the Internet the least; maximizers, below 70 years, who use the Internet for all activities; practical users, aged 71 years on average, who exploit the Internet for searching for information, comparing products or the Internet banking; and social users, mainly women, aged 71 years, who use the Internet for social and leisure activities. Most recently, more and more older people have used the Internet for searching for healthcare information (Bujnowska-Fedak, 2014; 2015). However, older people use only selected eHealth services which include, for example, obtaining information on their health, receiving reminders for scheduled visits, medication instructions, or consulting a doctor at a distance. Furthermore, they use Internet for searching health information about the right nutrition, exercise or weight issues, diseases 
such as cancer, heart disease, or arthritis, high cholesterol, and health providers (Kaiser Family Foundation, 2013).

Research also shows that the use of the Internet by older population groups may have a positive effect on enhancement of their cognitive functions, e.g., Almeida et al. (2012), Dodge et al. (2015), and thus, help in aging diseases such dementia. Almeida et al. (2012), for example, claim that the risk of incident of dementia was about $30 \%$ to $40 \%$ lower among older computer users than non-users. This has been confirmed by Tun and Lachman (2010) who state that the exploitation of computers is linked with improved cognitive competences in adulthood and old age.

The limitations of this study consist in a selective sample of the respondents located in one of the regions of the Czech Republic only and a lack of investigation of other factors such as educational or social status of the respondents.

\section{Conclusions}

Overall, the findings of this study indicate that the age (and respondents' previous experience in the Internet exploitation, e.g. at work) is a decisive factor in the use of the Internet by seniors. In fact, the use of the Internet falls with the increasing age, however, the breakthrough age seems to be $75+$ years. The results also suggest that older people should be trained in the use of the Internet since the training may help them overcome both psychological and social barriers, which represent the constraints in their use of the Internet. Furthermore, seniors could be divided into three basic age groups according to their special needs, which should be considered when designing new technological devices or services for these aging population groups, which could help them to enhance cognitive functions.

The authors are aware of the fact that the research sample is not representative but selective. Therefore, the results are valid for the geographical area and 'active' seniors interested in education in general, particularly in the field of ICT, as defined in the sample description. Any similar research has not yet been conducted within an identical or closely similar research sample (which includes the participants of the University of the Third Age and ICT courses for seniors) in the Czech Republic. However, research activities exploiting remotely resembling research samples were conducted e.g. by Rain and Svarcova (2010), Celer and Janska (2017) or by Slovak scholars, e.g. Hatar (2014), Jedlickova (2014) and Zimermanova (2012). The findings of this study contribute to the field of the Internet usage and relating services (activities). Mastering them is often connected with the family environment and family relations, as emphasized by Hatar (2014).

Future research should focus on each Internet activity mentioned in Fig. 4. The age level of 55 years defining the beginning of the senior age from the social view will probably not be increased in the future. However, the older adults falling in this group will have different (better) knowledge, as most of them will exploit ICT and the Internet for private and/or professional purposes. This is the main reason why the usage of the Internet will be topical in the future.

The paper is supported by the project Excellence (2203/2018) at the Faculty of Informatics and Management of the University of Hradec Kralove, Czech Republic.

\section{References}

Almeida, O. P., Yeap, B. B., Alfonso, H., Hankey, G. J., Flicker, L., \& Norman, P. E. (2012). Older Men Who Use Computers Have Lower Risk of Dementia. PLOS ONE, 7(8), e44239. https://dx.doi.org/10.1371/journal. pone.0044239.

Benáčová, H., \& Valenta, M. (2009). Moznosti informaticke vyuky senioru v ČR a EU. [Possibilities of Computer Science Teaching of Older People in the Czech Republic and EU.] Systémová integrace, 4, 77-86.

Bishop, J. (2009). Increasing Participation in Online Communities: A Framework for Human Computer Interaction. Computers in Human Behavior, 23(4), 1881-1893. https://dx.doi.org/10.1016/j.chb.2005.11.004.

Brush, A. B., Inkpen, K. M., \& Tee, K. (2008). SPARCS: Exploring Sharing Suggestions to Enhance Family Connectedness. In Proceedings of the 2008 ACM Conference on Computer Supported Cooperative Work (pp. 629-638). San Diego. https://dx.doi. org/10.1145/1460563.1460661.

Bujnowska-Fedak, M. M. (2015). Trends in the use of the Internet for health purposes in Poland. BMC, 15(194). https://dx.doi. org/10.1186/s12889-015-1473-3. 
Bujnowska-Fedak, M. M., \& Pirogowicz, I. (2014). Support for e-health services among elderly primary care patients. Telemedicine Journal and E-Health, 20(8), 696-704. https:// dx.doi.org/10.1089/tmj.2013.0318.

Celer, C., \& Janska, M. (2017). Online Habits of the 55 Plus Generation in a Selected Region of the Czech Republic. MARKETTRZISTE, 29(2), 125-138. https://dx.doi. org/10.22598/mt/2017.29.2.125.

Cerna, M., \& Svobodova, L. (2017). Internet and Social Networks as a Support for Communication in the Business Environment Pilot Study. In Proceedings of Hradec Economic Days 2017 (pp. 102-126). University of Hradec Kralove.

Cotten, S. R., Anderson, W. A., \& McCullough, B. M. (2013). Impact of Internet Use on Loneliness and Contact with Others Among Older Adults: Cross-Sectional Analysis. Journal of Medical Internet Research, 15(2), e39. https://doi.org/10.2196/jmir.2306.

Choi, N. G., \& DiNitto, D. M. (2013). Internet use among older adults: Association with health needs, psychological capital, and social capital. Journal of Medical Internet Research, 15(5), e97. https://dx.doi.org/10.2196/jmir.2333.

Czech Statistical Office. (2017a). Seniors. Retrieved May 16, 2017 from https://www.czso. $\mathrm{cz} / \mathrm{csu} / \mathrm{czso} /$ seniori.

Czech Statistical Office. (2017b). Population by one-year age and sex. Retrieved May 16, 2017 from https://vdb.czso.cz/vdbvo2/faces/en/index. jsf;jsessionid=HEB1rMEUbIS8yjTGoJjJroN2bn tU67fmRNQ7RcR64jPqYXCMROCx!1897923 919? page =vystup-objekt\&z=G\&f=GRAFICKY OBJEKT\&p vo=DEMD $001 \& c=v 3 \sim 2$ RP2015MP12DP31\&str=v4\&rouska=true\&clsp $=$ null.

d'Orsi, E., Xavier, A. J., Steptoe, A., de Oliveira, C., Ramos, L. R., Orrell, M., ... Marmot, M. G. (2014). Socioeconomic and Lifestyle Factors Related to Instrumental Activity of Daily Living Dynamics: Results from the English Longitudinal Study of Ageing. Journal of the American Geriatrics Society, 62(9), 1630-1639. https://doi.org/10.1111/jgs.12990.

Dodge, H. H., Zhu, J., Mattek, N. C. et al. (2015). Web-enabled conversational interactions as a method to improve cognitive functions: results of a 6-week randomized controlled trial. Alzheimer's \& Dementia: Translational Research \& Clinical Interventions, 1(1), 1-12. https://dx.doi.org/10.1016/j.trci.2015.01.001.
Dutton, W. H. (2009). The Fifth Estate Emerging through the Network of Networks. Prometheus, 27(1), 1-15. https://doi. org/10.1080/08109020802657453.

Fokkema, T., \& Knipscheer, K. (2007). Escape loneliness by going digital: A quantitative and qualitative evaluation of a Dutch experiment in using ECT to overcome loneliness among older adults. Aging \& Mental Health, 11(5), 496-504. https://doi. org/10.1080/13607860701366129.

Friemel, T. N. (2016). The digital divide has grown old: Determinants of a digital divide among seniors. New Media \& Society, 18(2), 313-331. https://doi.org/10.1177/1461444814538648.

Gell, N. M., Rosenberg, D. E., Demiris, G., LaCroix, A. Z., \& Patel, K. V. (2015). Patterns of Technology Use Among Older Adults With and Without Disabilities. The Gerontologist, 55(3), 412-421. https://doi.org/10.1093/geront/gnt166.

Godfrey, M., \& Johnson, O. (2009). Digital circles of support: Meeting the information needs of older people. Computers in Human Behavior, 25(3), 633-642. https://dx.doi. org/10.1016/j.chb.2008.08.016.

Groebner, D. F. et al. (2007). Business Statistics. A Decision-Making Approach. New Jersey: Pearson Prentice Hall.

Hanson, V. L. (2009). Age and web access: The next generation. In Proceedings of the 2010 W4A - Technical (pp. 7-15). Madrid. https://dx.doi.org/10.1145/1535654.1535658.

Hatar, C. (2014). Kvalita života inštitucionalizovaných seniorov $v$ edukačnom kontexte [Quality of Life of the Institutionalized Seniors within the Educational Context]. Nitra: UKF.

Heart, T., \& Kalderon, E. (2013). Older adults: are they ready to adopt healthrelated ICT? International Journal of Medical Informatics, 82(11), e209-e231. https://dx.doi. org/10.1016/j.jijmedinf.2011.03.002.

Helsper, E. J., Dutton, W. H., \& Gerber, M. M. (2009). To Be a Network Society: A CrossNational Perspective on the Internet in Britain [OII Research Report No. 17]. https://doi. org/10.2139/ssrn.1323813.

Hernandez-Encuentra, E., Pousada, M., \& Gomez-Zuniga, B. (2009). ICT and older people: Beyond usability. Educational Gerontology, 35(3), 226-245. https://dx.doi. org/10.1080/03601270802466934.

Hola, J., \& Pikhart, M. (2014). The Implementation of Internal Communication System as a Way to Company Efficiency. E\&M 
Ekonomie a Management, 17(2), 161-169. https://dx.doi.org/10.15240/tul/001/2014-2-012.

Jedlickova, P. (2014). Proseniorská výchova $\checkmark$ rodinách a institucionalizácia seniorov [Prosenior Education in Families and Seniors Institutionalization]. Nitra: UKF.

Lelkes, O. (2013). Happier and less isolated: internet use in old age. Journal of Poverty and Social Justice, 21(1), 33-46. https://doi. org/10.1332/175982713X664047.

Kaiser Family Foundation. (2013). E-health and the elderly: how seniors use the Internet for health information. Key findings from a national survey of older Americans. Retrieved October 9, 2017 from https:// kaiserfamilyfoundation.files.wordpress. com/2013/01/e-health-and-the-elderly-howseniors-use-the-internet-for-health-informationkey-findings-from-a-national-survey-of-olderamericans-survey-report.pdf.

Klimova, B. (2016). Use of the Internet as a prevention tool against cognitive decline in normal aging. Clinical Interventions in Aging, 11, 1231-1237. https://dx.doi.org/10.2147/CIA. S113758.

Klimova, B. (2017). Senior tourism and information and communication technologies. In J. Park, S. C. Chen, \& K. K. Raymond Choo (Eds.), Advanced Multimedia and Ubiquitous Engineering. FutureTech 2017. Lecture Notes in Electrical Engineering, vol 448 (pp. 440445). Singapore: Springer. https://dx.doi. org/10.1007/978-981-10.

Klimova, B., \& Maresova, P. (2017). Computer-based training programs for older people with Mild Cognitive Impairment and/or dementia. Frontiers in Human Neuroscience, 11, 262. https://dx.doi.org/10.3389/ fnhum.2017.00262.

Klimova, B., Simonova, I., Poulova, P., Truhlarova, Z., \& Kuca, K. (2016). Older people and their attitude to the use of information and communication technologies - A review study with special focus on the Czech Republic (Older people and their attitude to ICT). Educational Gerontology, 42(5), 361-369. https://dx.doi.org /10.1080/03601277.2015.1122447.

Maresova, P., Klimova, B., \& Kuca, K. (2015a). Alzheimer's disease: Cost cuts call for novel drugs development and national strategy. Ceska a slovenska farmacie, 64, 25-30.

Maresova, P., Mohelska, H., Valis, M., \& Kuca, K. (2015b). Alzheimer disease and its treatment costs: case study in the Czech.
Neuropsychiatric Disease and Treatment, 11, 2349-2354. https://dx.doi.org/10.2147/NDT. S87503.

Office for National Statistics. (2016). Internet users in the UK: 2016. Retrieved May 20, 2017 from https://www.ons.gov.uk/ businessindustryandtrade/itandinternetindustry/ bulletins/internetusers/2016.

Patterson, I. (2006). Growing older. Tourism and leisure behaviour of older adults. Cambridge: Cabi. https://dx.doi. org/10.1079/9781845930653.0000.

Pew Research Center. (2017). Internet/ Broadband fact sheet. Retrieved May 23, 2017 from http://www.pewinternet.org/fact-sheet/ internet-broadband/.

Prior, S., Arnott, J., \& Dickinson, A. (2008). Interface metaphor design and instant messaging for older adults. In Proceedings of CHI 08 Extended Abstract on Human Factors in Computing Systems (pp. 3747-3752). Florence. https://dx.doi.org/10.1145/1358628.1358924.

Rain, T., \& Svarcova, I. (2010). Internet and Seniors. Journal on Efficiency and Responsibility in Education and Science, 3(2), 79-85.

Sayago, S., \& Blat, J. (2010). Telling the story of older people e-mailing: an ethnographical study. International Journal of Human-Computer Studies, 68(1-2), 105-120. https://dx.doi.org/10.1016/j.ijhcs.2009.10.004.

Sayago, S., Sloan, D., \& Blat, J. (2011). Everyday use of computer-mediated communication tools and its evolution over time: An ethnographical study with older people. Interacting with Computers, 23(5), 543-554. https://dx.doi.org/10.1016/j. intcom.2011.06.001.

Slavik, L. (2012). Senior tourism (Diploma Thesis). Praha: Charles University in Prague.

Smith, A. (2014). Older adults and technology use. Retrieved June 9, 2017 from http://www.pewinternet.org/2014/04/03/olderadults-and-technology-use/.

Taha, J., Sharit, J., \& Czaja, S. (2009). Use of and Satisfaction with Sources of Health Information among Older Internet Users and Nonusers. The Gerontologist, 49(5), 663-673. https://doi.org/10.1093/geront/gnp058.

The $R$ Project for Statistical Computing. (2017). Retrieved May 20, 2017 from https://www.r-project.org/.

Transgenerational Design Matters. (2009). Retrieved March 10, 2017 from 
http://transgenerational.org/aging/ demographics.htm.

Tsai, H. S., Shillair, R., \& Cotten, S. R. (2017). Social Support and "Playing Around": An Examination of How Older Adults Acquire Digital Literacy with Tablet Computers. Journal of Applied Gerontology, 36(1), 29-55. https://doi.org/10.1177/0733464815609440.

Tun, P. A., \& Lachman, M. E. (2010). The association between computer use and cognition across adulthood: use it so you won't lose it? Psychology and Aging, 25(3), 560-568. https://dx.doi.org/10.1037/a0019543.

van Boekel, L. C., Peek, S. T., \& Luijkx, K. G. (2017). Diversity in older adults' use of the Internet: Identifying subgroups through latent class analysis. Journal of Medical Internet Research, 19(5), e180. https://dx.doi. org/10.2196/jmir.6853.

Virginia Assistive Technology System. (2011). Assistive technology and Aging. $A$ handbook for Virginians who are aging and their caregivers. Retrieved May 19, 2017 from http://www.vda.virginia.gov/pdfdocs/ Assistive\%20Technology $\% 20 \& \% 20$ Aging $\% 20$ -\%20All.pdf.

de Veer, A. J. E. et al. (2015). Determinants of the intention to use e-Health by community dwelling older people. BMC Health Services Research, 15(103), 1-9. https://dx.doi. org/10.1186/s12913-015-0765-8.

Yuan, S., Hussain, S. A., Hales, K. D., \& Cotten, S. R. (2016). What do they like? Communication preferences and patterns of older adults in the United States: The role of technology. Educational Gerontology, 42(3), 163-174. https://doi.org/10.1080/03601277.20 15.1083392.

Zheng, R. Z., Hill, R. D., \& Gardner, M. K. (2013). Engaging older adults with modern technology: Internet use and information access needs. USA: Information Science Reference. https://dx.doi.org/10.4018/978-1-4666-1966-1.
Zickuhr, K., \& Madden, M. (2012). Older adults and internet use. Retrieved May 9, 2017 from http://www.pewinternet.org/files/oldmedia/Files/Reports/2012/PIP_Older_adults_ and_internet_use.pdf.

Zimermanova, M. (2012). Kooperácia detí a seniorov $v$ rezidenciálnych podmienkach [Children- Senior Co-operation under the Institutionalized Conditions]. Nitra: UKF.

doc. PhDr. Blanka Klímová, M.A., Ph.D. University of Hradec Kralove Faculty of Informatics and Management Czech Republic blanka.klimova@uhk.cz

doc. RNDr. Petra Poulová, Ph.D. University of Hradec Kralove

Faculty of Informatics and Management Czech Republic petra.poulova@uhk.cz

doc. PhDr. Ivana Šimonová, PhD. Jan Evangelista Purkyně University Faculty of Education Czech Republic ivana.simonova@ujep.cz

doc. RNDr. Pavel Pražák, Ph.D. University of Hradec Kralove Faculty of Informatics and Management Czech Republic pavel.prazak@uhk.cz

dr hab. inž. Anna Cierniak-Emerych, prof. UE Wroclaw University of Economics Faculty of Engineering and Economics Poland anna.cierniak-emerych@ue.wroc.pl 


\section{Abstract}

\section{INTERNET USE BYTHE OLDER ADULTS IN THE CZECH REPUBLIC \\ Blanka Klímová, Petra Poulová, Ivana Šimonová, Pavel Pražák, Anna Cierniak-Emerych}

Ageing is becoming a big social issue nowadays. For example, in 2000 the percentage of older individuals aged $65+$ years reached $12.4 \%$ worldwide. In 2030 , this number should rise to $19 \%$ and in 2050 to $22 \%$. Therefore, there is a need to prolong an active life of older people, especially by implementing non-pharmacological approaches. Current technological devices and services can assist them in this process. Therefore, the purpose of this study is to explore the use of the Internet among older people in the Czech Republic with respect to their age. The key methods exploited in this study include a questionnaire survey, statistical processing of data collection, as well as evaluation of both empirical and theoretical findings on the research issue. The results indicate that the age is a decisive factor in the use of the Internet by seniors. In fact, the use of the Internet falls with the declining age with the breakthrough age 75+years. Generally, older people use the Internet for communication purposes with the help of e-mail, the most frequent ICT tool for this generation group. Nevertheless, the findings of this study show that the second most common reason for the use of the Internet is the Internet banking, followed by Skype communication and photo sharing. The results also suggest that older people should be trained in the use of the Internet since the training may help them overcome both psychological and social barriers, which represent the constraints in their use of the Internet. Furthermore, seniors could be divided into three basic age groups according to their special needs, which should be considered when designing new technological devices or services for these aging population groups, which could help them to enhance cognitive functions.

Key Words: Elderly, Internet, age group, Internet usage, survey.

JEL Classification: C12, C99, D64, I31, O35.

DOI: 10.15240/tul/001/2018-3-014 